\title{
Production of a Novel Halophilic Dextranase from a Honey Isolate, Bacillus subtilis NRC-B233 under Solid-state Fermentation
}

\author{
Sara H. Mansour, Eman F. Ahmed, Naziha M. Hassanein* \\ and Mona A. Esawy \\ Department of Microbial and Natural Products Chemistry, \\ National Research Centre and "Department of Microbiology, \\ Faculty of Science, Ain Shams University, Cairo, Egypt.
}

\begin{abstract}
A
GRAM-POSITIVE, sporulating halophilic bacteria, designated NRC-B233, was isolated from the honey produced in Saudi Arabia. It was identified by the $16-23 \mathrm{~S}$ intergenic region as Bacillus subtilis NRC-B233. Screening of the wastes and agro-products for dextranase production under solid state fermentation showed that corn flour was the best substrate $(61.323 \mathrm{U} / \mathrm{g})$. The optimum conditions for dextranase productions were $37^{\circ} \mathrm{C}, \mathrm{pH} 9,32 \mathrm{hr}$ incubation period, and $200 \%$ moisture content. The most favorable nitrogen and carbon sources for enzyme production were $2 \%$ peptone and $5 \%$ starch $(1076.768,1553.364 \mathrm{U} / \mathrm{g})$. respectively. A unique character of this isolate is its ability to continuously produce dextranase in the absence and presence of $\mathrm{NaCl} 5-20 \mathrm{~g} / \mathrm{l}$. The addition of $0.175 \mathrm{Mm} \mathrm{CrCl}_{3}$ increased the dextranase production about 4.5 fold. The enzyme has been partially purified about 112 -fold from crude extract by only two purification steps involving ultra-filtration. The purified dextranase showed its maximum activity at $\mathrm{pH} 9.2$ and $70^{\circ} \mathrm{C}$. It retained full activity $(100 \%)$ at $75^{\circ} \mathrm{C}$ for one hour. Dextranase activity increased about four fold in the presence of $10 \% \mathrm{NaCl}$. On the other hand, $\mathrm{CaCl}_{2}(0.050 \mathrm{M})$, EDTA $(0.100 \mathrm{M})$, and $\mathrm{KCl}(0.100 \mathrm{M})$ had great influence in enzyme activity. The enzyme showed variable degradation effects on different types of dextran and its derivatives.

These results suggest that the dextranase secreted by Bacillus subtilis NRC-B233 is industrially important from the perspectives of its activity at across $\mathrm{pH}$ range (5.0-10.0), its thermo-activity in addition to its halophilic character and its ability to degrade different types of $\alpha-1,4$ and $\alpha-1,6$ glycosidic linkages.
\end{abstract}

Keywords: Halophilic dextranase, Bacillus subtilis, Dextranase stability.

Honey is a reservoir for microbes that withstand concentrated sugar levels , acidity, as well as also it has antimicrobial characteristics. The osmophilic feature of the honey could hypothesize the presence of moderate halophilic bacteria with new properties. Recently, a considerable attention has been given Correspondence authors: mona_esawy@hotmail.com, emanfad169@yahoo.com 
to the enzymes produced by moderately halophilic microorganisms and their biotechnological potentials (Ventosa et al., 1998, Xue and et al., 2008). Enzymes with optimal activity at high-salt concentrations are useful for many harsh industrial processes, where concentrated salt solutions otherwise inhibit many enzymatic conversions ( Amoozegar et al., 2003; Hutcheon et al., 2005 and Oren et al., 2005). Halophilic enzymes perform the same enzyme function as their non halophilic counterparts, but they have substantially different properties. Among these are their requirements for high-salt concentrations in the 1-4 $\mathrm{M}$ range for activity and stability. Extremely and moderately halophilic microorganisms have been well described, but the apparent thermostable properties of their enzymes especially from moderately halophilic bacteria, have not (Tokunaga et al., 2004).

Dextran is a collective name for high-molecular-weight polymers composed of D-glucose units connected with $\alpha-1,6$ linkages and various amounts of side branches linked with $\alpha-1,2, \alpha-1,3$, or $\alpha-1,4$ to the main chains. Dextranase (EC 3.2.1.11; _-1, 6-glucan 6-glucanohydro- hydrolyzes the 1-6 glycosidic linkage in dextran (Sankpal et al., 2001). The enzyme cleaves the linkages of the dextran molecule and releases shorter isomaltosaccharides. It occurs in a variety of bacteria, e.g: Bacillus subtilis and B.megaterium ( Hayward \& Sly,1976). In the sugar-processing industry, contamination by dextran causes an extensive problem by increasing the viscosity of the sugar juice. The use of dextranase in the processing, however, reduces the viscosity (Clarke, 1997). For dental and industrial uses, it is necessary to use a dextranase which is stable and has an optimum $\mathrm{pH}$ range of neutral to alkaline. A large number of industrial processes in the environmental industry and food biotechnology utilize enzymes at some stage or the other. Current developments in biotechnology are yielding new applications for such enzymes. Solid state fermentation (SSF) holds tremendous potential for the production of enzymes. It can be of special interest in those processes where the crude fermented products may be used directly as enzyme sources. Among the several factors that are important for microbial growth and enzyme production using a particular substrate are particle size and moisture level/water activity (Pandey, 1992, 1994).

The aim of the present study was to examine the production of dextranase under SSF using Bacillus subtilis isolated from honey and to optimize the fermentation medium for maximum enzyme activity. Furthermore, partial purification and characterization of dextranase were investigated in our research.

\section{Materials and Methods}

\section{Isolation of bacterial strain from honey}

The isolate NRC-B233 was isolated from honey produced in Saudi Arabia. One hundred microliters of honey was spread on solid agar plates $(\mathrm{g} / \mathrm{l})$ : dextran, $10 ; \mathrm{MgSO}_{4}, 0.02 ; \mathrm{K}_{2} \mathrm{HPO}_{4}, 5.5$ and agar, 25. After drying for $20 \mathrm{~min}$ in a laminar flow hood, the plates were incubated at $50^{\circ} \mathrm{C}$ for $24 \mathrm{hr}$ or until the bacterial Egypt. J. Microbiol. 46 (2011) 
colonies were of a sufficient size for colony replication (approximately larger than 3-5 $\mathrm{mm}$ in diameter). The bacterial isolates were streaked onto fresh agar plates and preserved at $4{ }^{\circ} \mathrm{C}$. The purity of the isolate was assessed by colony morphology and microscopy.

\section{Identification of the isolate}

The isolate was identified as a novel Bacillus subtilis NRC-B233 on the base of 16S rRNA sequence and 16-23S intergenic region (Lopez \& Alippi, 2007; Rodriguez et al., 2007 and Shah et al., 2007). DNA extraction and PCR amplification of 156srDNA region. DNA was isolated from the selected isolates coded KNRC1410 according to Sambrook et al. (1989). The 16srDNA was amplified by polymerase chain reaction (PCR) using primers designed to amplify $1500 \mathrm{bp}$ fragment of the 16srDNA region. The forward primer was 5'AGAGTTTGATCMTGGCTCAG3' and the reverse primer was 5'TACGGYTACCTTGTTACGACTT3'. The PCR mixture consists of 30 picomoles of each primer, 10ng of chromosomal DNA, $200 \mu \mathrm{M}$ dNTPs and 2.5 Units of Taq polymerase in $50 \mu \mathrm{l}$ of polymerase buffer. The PCR was carried out for 30 cycles in $94^{\circ} \mathrm{C}$ for $1 \mathrm{~min}, 55^{\circ} \mathrm{C}$ for $1 \mathrm{~min}$ and $72^{\circ} \mathrm{C}$ for $2 \mathrm{~min}$. After completion, a fraction of the PCR mixture was examined using agarose gel electrophoresis (Ausuble et al., 1999) (Fig.1) and the remnant was purified using QIAquick PCR purification reagents (Qiagen). DNA sequences were obtained using an $3130 \mathrm{X}$ DNA Sequencer (Genetic Analyzer, Applied Biosystems, Hitachi, Japan), BigDye Terminator Cycle Sequencing (see details below). The PCR product was sequenced using the PCR primers described above. Blast program was used to asses the DNA similarities and multiple sequence alignment and molecular phylogeny were performed using BioEdit software (Hall, 1999). The phylogenetic tree was displayed using the TREEVIEW program (Page, 1996).

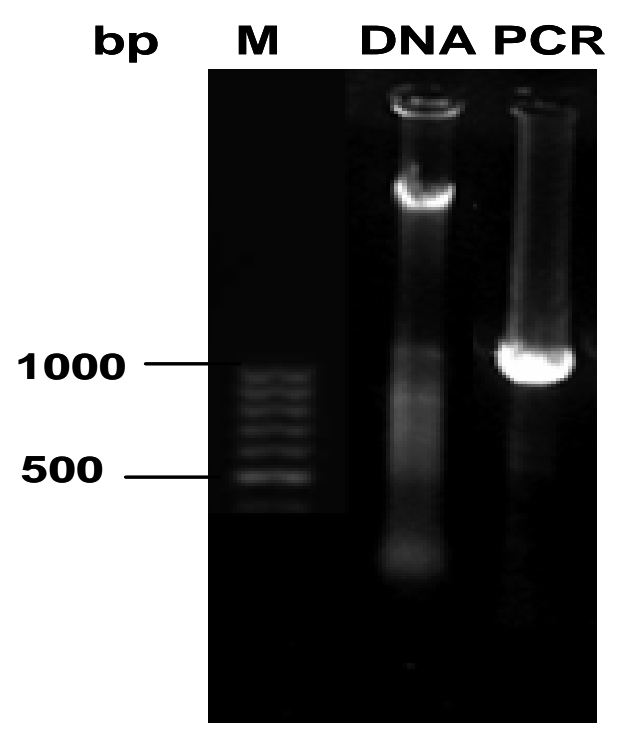

Fig. 1. Agarose gel electrophores.

Egypt. J. Microbiol. 46 (2011) 
DNA sequencing

Automated DNA sequencing based on enzymatic chain terminator technique, developed by Sanger et al. (1977), was done using 3130 X DNA Sequencer (Genetic Analyzer, Applied Biosystems, Hitachi, Japan). The sequencing reaction was performed with four different fluorescent labels identifying the ddNTPs, instead of the radioactive labels. These flurophores were excited with two argon lasers at 488 and $514 \mathrm{~nm}$, respectively when the respective bands passed the lasers during the electrophoresis. The specific emissions were detected and the data were collected for analysis (Prober et al., 1987 and Freeman et al., 1990). The thermal cycling mixture was as follows: $8 \mu \mathrm{l}$ of BigDye terminator mix, $6 \mu 1$ of the sequencing primer $(10$ pmol) and $6 \mu 1$ of the sample (PCR product or plasmid), then the reaction was run in the thermal cycler. The cyclic reaction composed of $1 \mathrm{~min}$ at $95^{\circ} \mathrm{C}$, then 49 cycles of $30 \mathrm{sec}$ at $95^{\circ} \mathrm{C}, 10 \mathrm{sec}$ at $52^{\circ} \mathrm{C}$ and $4 \mathrm{~min}$ at $60^{\circ} \mathrm{C}$. The products were purified using special column according to the instruction of the manufacturer. The elute were taken and add high dye formamide with (1:1)/volume ratio, run at $95^{\circ} \mathrm{C}$ for $5 \mathrm{~min}$ for denaturation, shocked on ice. The sample sequenced in $3130 \mathrm{X}$ DNA sequencer and analysised.

\section{Chromosomal DNA and plasmid extraction}

Chromosomal DNA was prepared from overnight culture in LB (in full at first mention), using AxyGEN BIOSCIENCES DNA extraction kit, according to Manufacturer's Instructions. Plasmid extraction was performed using Wizard mini prep. extraction kit (Promega) according to the manufacturer's instructions with slight modification, briefly $50 \mu \mathrm{l}$ of lysozyme $(200 \mathrm{mg} / \mathrm{ml})$ was added to the resuspended buffer and incubated at $37^{\circ} \mathrm{C}$ for $1 \mathrm{hr}$ then the protocol was carried on as described in the kit.

\section{PCR amplification for molecular identification}

To amplify the 16S rRNA gene, a primer pair hybridizing to two conserved regions in 16S rRNA genes from Bacillus spp. was used: (bac-F and bac-R) (Ash et al., 1991). For the amplification of the 16-23S intergenic region, a primer pair was used: L516SF and L523SR.

\section{Dextranase production media}

The medium used to test the dextranase production had the following composition (g/l): dextran, 10; yeast extract, 2.5; $\mathrm{MgSO}_{4}, 0.02 ; \mathrm{K}_{2} \mathrm{HPO}_{4}, 5.5$ (each separately autoclaved).

\section{Cellular production}

Cultivation was carried out in 250-ml Erlenmeyer flasks. Each flask contained $50 \mathrm{ml}$ of production medium and was sterilized for $15 \mathrm{~min}$ at $121^{\circ} \mathrm{C}$. The flasks were then inoculated with $2.0 \mathrm{ml}$ spore suspention and incubated in a static incubator for $24 \mathrm{hr}$ at $30^{\circ} \mathrm{C}$. The culture broth was then centrifuged in a refrigerated centrifuge (K70; Janektzki, Germany) at $10,397 \mathrm{~g}$ to separate the bacterial cells from the culture medium. Each fermentation run was performed in

Egypt. J. Microbiol. 46 (2011) 
triplicate, and analyses were carried out in duplicate. The data given are the means of all the measurements. The mean standard error of the dextranase estimate was f 0-25 $\mathrm{U}$ and ranged from f0.002 to $\mathrm{f} \pm 3.997$.

\section{Solid- state experiment}

Ten grams of each substrate in 250 Erlenmeyer flasks (taro crust-, apple crust,- banana crust-, onion crust-, potato crust -, egg plant crust-, watermelonrind, sawdust-, corn flour-, wheat flour-, commercial starch-, wheat bran or ground rice) were mixed with $8 \mathrm{ml}$ of the production medium together with $10 \mathrm{ml}$ of distilled water, mixed thoroughly and autoclaved at $121^{\circ} \mathrm{C}$ for $30 \mathrm{~min}$. They were cooled at room temperature and each flask was inoculated with $2 \mathrm{ml}$ inoculum.

\section{Extraction and enzyme recovery}

Dextranase was extracted from the substrate using distilled water as the extracting agent (Balch et al., 1979). Ten volumes of distilled water per gram substrate (based on initial dry weight of the substrate) was added to the fermented medium and the extraction was performed by agitation at room temperature in a rotary shaker for $60 \mathrm{~min}$ at $150 \mathrm{rpm}$. The slurry was then squeezed through Sun dried muslin cloth previously washed in distilled water and clarified by centrifugation at $5,000 \mathrm{rpm}$ at $4^{\circ} \mathrm{C}$ for $15 \mathrm{~min}$. The clear supernatant was used to assay for the enzyme activity and protein content.

\section{Assay of enzyme activity}

The activity was measured using the Somogi-Nelson method (Somogi, 1952) with dextran (Mol.Wt.250000) as substrate; $0.3 \mathrm{ml}$ of the filtrate medium was incubated with $0.7 \mathrm{ml}$ of $2.5 \%$ dextrane (Mol.Wt.250000) in $0.1 \mathrm{M}$ sodium citrate buffer at $\mathrm{pH} 5.2$ and $50^{\circ} \mathrm{C}$ for $15 \mathrm{~min}$. Then $0.25 \mathrm{ml}$ was taken for the assay.

One unit (U) of enzyme was defined as the amount of enzyme which liberated $1 \mu \mathrm{g}$ of glucose equivalent in one min. Amount of protein was determined by the method of (Lowry et al., 1956).

\section{Chromatography}

Paper chromatography was performed according to Block et al. (1995). Hydrolytic products from dextran (Mol.Wt.250000) were analyzed by paper chromatography on whatman No.1. The reaction mixtures at the end of incubation time were boiled for $3 \mathrm{~min}$ to stop the reaction. Chromatographic development was carried out with a solvent system of n-butanol: acetone: water $(4: 5: 1)$ and detected by spraying with aniline hydrogen phthalate.

\section{Optimization of culture conditions}

All the following experiments were conducted under SSF in the presence of corn flour as the best substrate.

The influence of temperature on growth and production of dextranase was studied at $25^{\circ} \mathrm{C}, 30^{\circ} \mathrm{C}, 37^{\circ} \mathrm{C}, 50^{\circ} \mathrm{C}$ and $60^{\circ} \mathrm{C}$. The effect of the incubation period was studied at $(8,24,32,48,56$ and $72 \mathrm{hr})$, at $37^{\circ} \mathrm{C}$. Effect of moisture content 
was achieved using different volumes of distilled water $(50,100,150,200,250$, 300 and $500 \%(\mathrm{v} / \mathrm{w}))$ at $37^{\circ} \mathrm{C}$. Dextranase production was also investigated with the initial $\mathrm{pH}$ adjusted to $3.2,4.2,5.2,6.2,7.2,8.2,9.2$ and 10.2 at $37^{\circ} \mathrm{C}$.

\section{Nutrient additives}

Nutrient additives included $\mathrm{NaCl}(5-35 \mathrm{~g} / \mathrm{l})$ and $0.1 \mathrm{M}\left(\mathrm{FeSO}_{4}, \mathrm{EDTA}, \mathrm{MnCl}_{2}\right.$, $\mathrm{NaH}_{2} \mathrm{PO}_{4}, \mathrm{FeCl}_{3}, \mathrm{LiSO}_{4}, \mathrm{MgSO}_{4}, \mathrm{~K}_{2} \mathrm{Cr}_{2} \mathrm{O}_{7}, \mathrm{KI}, \mathrm{K}_{2} \mathrm{HPO}_{4}, \mathrm{Na}_{2} \mathrm{HAsO}_{4}, \mathrm{ZnSO}_{4}$, $\mathrm{K}_{2} \mathrm{~S}_{2} \mathrm{O}_{8}, \mathrm{KH}_{2} \mathrm{PO}_{4}, \mathrm{CaCl}_{2}, \mathrm{KCl}, \mathrm{AlCl}_{3}, \mathrm{CuSO}_{4}$ and $\mathrm{NaCO}_{3}$ ) with each salt added separately in the production medium. Also (5g/l) of the different organic nitrogen sources; urea, beef extract, yeast extract, ammonium chloride, peptone, casein and corn steep were used. In addition, different carbon sources ; (5g/l) (manose, glucose, galactose, sucrose, lactose, arabinose, cellulose, dextrane, xylose, starch and dextrin ) were added in the medium to study their effects on dextranase activity.

\section{Storage stability}

The culture filtrate of the crude dextranase enzyme was stored in distilled water at $4^{\circ} \mathrm{C}$ for four months. The activity was measured every two weeks using $3.5 \mathrm{mg}$ of protein.

\section{Partial purification of dextranase}

The ultra-filtration and fractional precipitation with acetone techniques were used. The first step of purification was carried out by passing 2 liters of crude enzyme through a Pellicon Cassette system with a membrane PLGC Cassette 10.000 NMWL. Low protein binding . The retentate and permeate obtained were checked for dextranase activity. The permeate fraction exhibited a dextranase activity.

Fractional precipitation using different concentrations (30-80\%) of acetone by (Fukomoto, 1963) was used. The method was performed as follows: $100 \mathrm{ml}$ permeate fraction was precipitated using $30 \% \mathrm{v} / \mathrm{v}$ solvent and centrifuged at $2850 \mathrm{~g}$ for $10 \mathrm{~min}$ in a cooling centrifuge, (fraction 1) then $40 \% \mathrm{v} / \mathrm{v}$ solvent was used to precipitate the supernatant (fraction 2). This method was repeated to reach to $80 \% \mathrm{v} / \mathrm{v}$ solvent concentration and the fraction that contained the highest enzyme activity was chosen for further experiments.

Effect of $p H$ on partially purified dextranase

Enzyme activity was studied over the pH range 3.2-10.2.

\section{Influence of incubation temperature}

In this experiment, $0.3 \mathrm{ml}$ of partially purified enzyme was incubated with $0.7 \mathrm{ml}$ of $2.5 \%$ dextrane and incubated at different temperatures $\left(35-75^{\circ} \mathrm{C}\right)$ for $15 \mathrm{~min}$.

\section{Thermal stability}

Profile was studied by incubating the enzyme preparation at various temperatures, $\left(40-75^{\circ} \mathrm{C}\right)$ in glycine $\mathrm{NaOH}$ buffer $0.05 \mathrm{M}$, at $\mathrm{pH} 10$ for different incubation period $(15-60 \mathrm{~min})$ and the residual activity was measured at $70^{\circ} \mathrm{C}$.

Egypt. J. Microbiol. 46 (2011) 
The pH stability of dextranase enzyme was examined by incubating the enzyme at room temperature at $0.5,1,1.5,2 \mathrm{hr}$ and different $\mathrm{pH}$ values 5.2 and 6.2 of $(0.1 \mathrm{M})$ sodium - citrate buffer, 7.2 and 8.2 of $(0.2 \mathrm{M})$ tris buffer and 9.2 and 10.2 of $(0.2 \mathrm{M})$ glycine $-\mathrm{NaOH}$ buffer.

The residual activity was measured as mentioned previously.

Influence of salts on enzyme activity

One $\mathrm{ml}$ of partially purified enzyme was dissolved in $1 \mathrm{ml}$ of $0.1 \mathrm{M}$ of the following salts: $\mathrm{MnCl}_{2}, \mathrm{CrCl}_{3}, \mathrm{EDTA}, \mathrm{CaCl}_{2}, \mathrm{MgSO}_{4} .7 \mathrm{H}_{2} \mathrm{O}, \mathrm{CuSO}_{4} .5 \mathrm{H}_{2} \mathrm{O}$, $\mathrm{AlCl}_{3} \cdot 6 \mathrm{H}_{2} \mathrm{O}, \mathrm{CaCO}_{3}, \mathrm{KCl}$ and $\mathrm{ZnSO}_{4} \cdot 7 \mathrm{H}_{2} \mathrm{O}$, then incubated with the substrate and the activity was measured.

Effect of different concentrations of $\mathrm{NaCl}$

One $\mathrm{ml}$ of partially purified enzyme was dissolved in $1 \mathrm{ml}$ of different concentrations $(1-15 \%) \mathrm{NaCl}$ and incubated at room temperature for one hour. The enzyme activity was determined as described previously.

Effect of enzyme on different molecular weights of dextrans

Partially purified enzyme was used to degrade dextrans of different molecular weights (250 000 and 275000) blue dextran (2000) and sephadex G-100(100010000). Also some carbohydrates such as starch, amylopectin, cellulose, maltose and inulin were used .

\section{Results}

\section{Characteristics of dextranase producing bacteria}

The cells isolated from Saudi Arabian kashmiry honey were rod shaped Gram positive, motile and spore forming. Colonies were circular and cream, no pigment formed. The isolate was subjected to molecular identification based on $16 \mathrm{~S}$ rRNA gene sequencing method (Fig.1). The 16S rRNA gene sequence analysis indicated that the isolate was Bacillus sp. with $98 \%$ identity to any of these three species Bacillus spp., or B. licheniformis, or B. subtilis and they clustered into a monophyletic line in a phylogenetic tree.

To identify the isolate to a definite species the analogical electrophoresis, using NEB cutter was applied to identify the $16 \mathrm{~S}$ rRNA results, which have been sequenced. The isolate showed different AluI fragments which differ to the AluI fragments generated from $16 \mathrm{~S}$ rRNA sequence of $B$. subtilis, or $B$. licheniformis or $B$. amyloliquefaciens. It was clear that $16 \mathrm{~S}$ rRNA gene alone could not distinguish this isolate.

\section{Identification by 16-23S intergenic region}

For complete identification of this isolate the 16-23S intergenic region was amplified with the primers L516SF X L523SR, then the sequence was determined for the isolate. The homology results for the 16-23S intergenic region reported that: the isolate NRC-B233 was $100 \%$ identical to B. subtilis . 
Dextranase production and the effect of different parameters

The preliminary experiment using the shack culture technique and dextran as a substrate revealed that Bacillus subtilis NRC-B233 exhibited high dextrane degradation (258 Ulml), so it was chosen for this study. The chromatography of the compounds produced by incubating dextran (250000) with the crude enzyme suggested a random endo-type hydrolysis resulting in liberation of long-chain oligomers together with glucose and isomaltose units. Accordingly, different types of wastes products and cheap materials were applied under SSF using shaken and static conditions. Dextranase activity was produced in the presence of corn flour, - wheat flour - wheat bran, -commercial starch, - grinded rice (Fig. 2). The highest activity was achieved using corn flour $(75.276,61.323 \mathrm{U} / \mathrm{g}$ ) shaken and static, respectively. The optimum temperature for maximum enzyme production was obtained at $37^{\circ} \mathrm{C}(140.177,108.192 \mathrm{U} / \mathrm{ml}$ shaken and static, respectively, below and above this temperature there was a clear decrease in enzyme production (Fig. 3). The difference between the shaking and static was significant. Consequently the cultures in the following experiments were incubated statically in order to save energy. The enzyme activity was increased by increasing the time of incubation to reach the maximum value $(158.961 \mathrm{U} / \mathrm{g})$ after $32 \mathrm{hr}$. There was a gradual decrease in enzyme activity between (48 and $72 \mathrm{hr}$ ) (Fig. 4). The optimum dextranase production (170.624 U/g corn flour) was observed at $200 \%$ (v/w) moisture level (Fig. 5). Bacillus subtilis produced dextranase across $\mathrm{pH}$ range from 3 to 11 and the maximum enzyme production was obtained at pH10 $(216.134 \mathrm{U} / \mathrm{g})$ (Fig. 6). The addition of $\mathrm{NaCl}(5-20 \mathrm{~g} / \mathrm{l})$ had no influence on enzyme production. Concentrations higher than $20 \mathrm{~g} / \mathrm{l}$ reduced enzyme production gradually and at $35 \mathrm{~g} / 1 \mathrm{NaCl}$ enzyme activity was reduced by $55 \%$ (Fig. 7). The influence of different salts ( $(0.1 \mathrm{M})$ on dextranase production had variable effects on dextranase production. The production increased in the presence of $\mathrm{KCl}$ and $\mathrm{AlCl}_{3}$ with the maximum activity in the presence of $\mathrm{CrCl}_{3}(447.580 \mathrm{U} / \mathrm{g})$. The influence of different concentrations of $\mathrm{CrCl}_{3}$ (0.025- $2 \mathrm{M})$ on the enzyme activity showed that a gradual increase in activity was obtained by increasing the concentration of $\mathrm{CrCl}_{3}$ and $0.175 \mathrm{M}$ was the optimum for enzyme productivity (Fig. 8b). Different organic nitrogen sources $(5 \mathrm{~g} / \mathrm{l})$ were separately added to the fermentation media to evaluate their effects on dextranase activity and $(5 \mathrm{~g} / \mathrm{l})$ casein, ammonium chloride, yeast extract and corn steep increased its activity (Fig. 9a). The maximum activity (1076.768 U/g) was obtained when $(5 \mathrm{~g} / \mathrm{l})$ peptone was added. On the other hand, urea, malt extract and beef extract decreased the activity compared to the control ( without nitrogen source ).

$2 \%$ peptone provided the best dextranase activity (1225 U/g) (Fig. 9b). Whilst the best carbon source was $(5 \mathrm{~g} / \mathrm{l})$ starch producing a dextranase activity of $1553.364 \mathrm{U} / \mathrm{g}$ (Fig. 10), whilst, dextrin, mannose and fructose reduced the enzyme production to $67 \%, 84 \%$ and $75 \%$, respectively. 


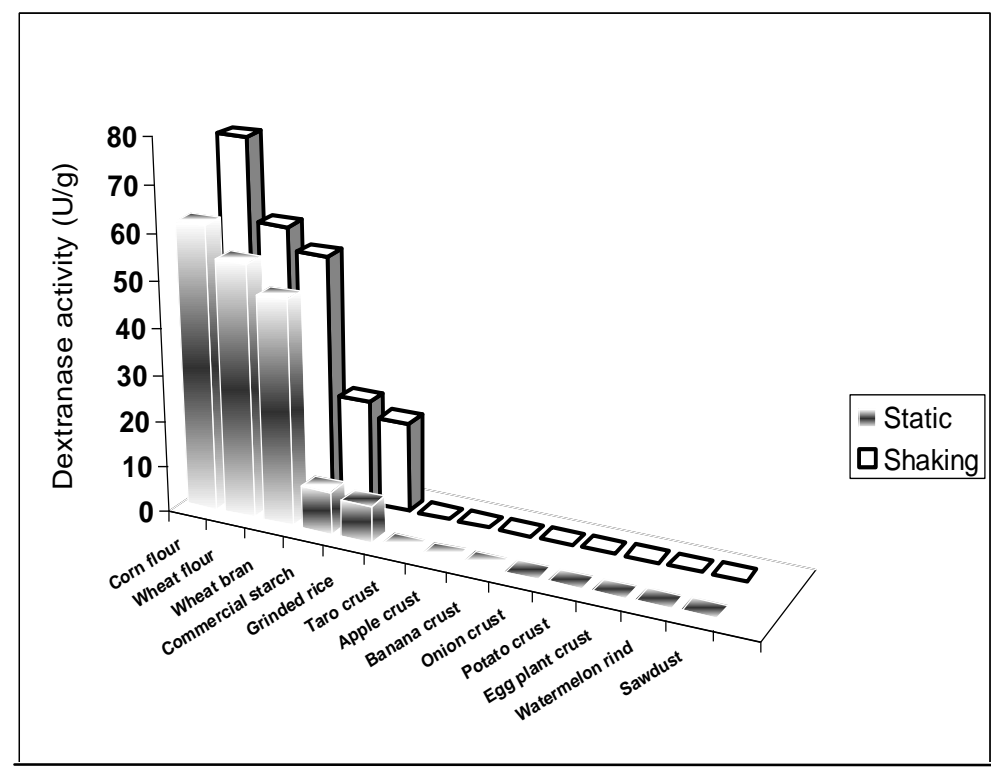

Fig. 2. Effect of different wastes and commercial materials on dextranase production from Bacillus subtilis KNRC.

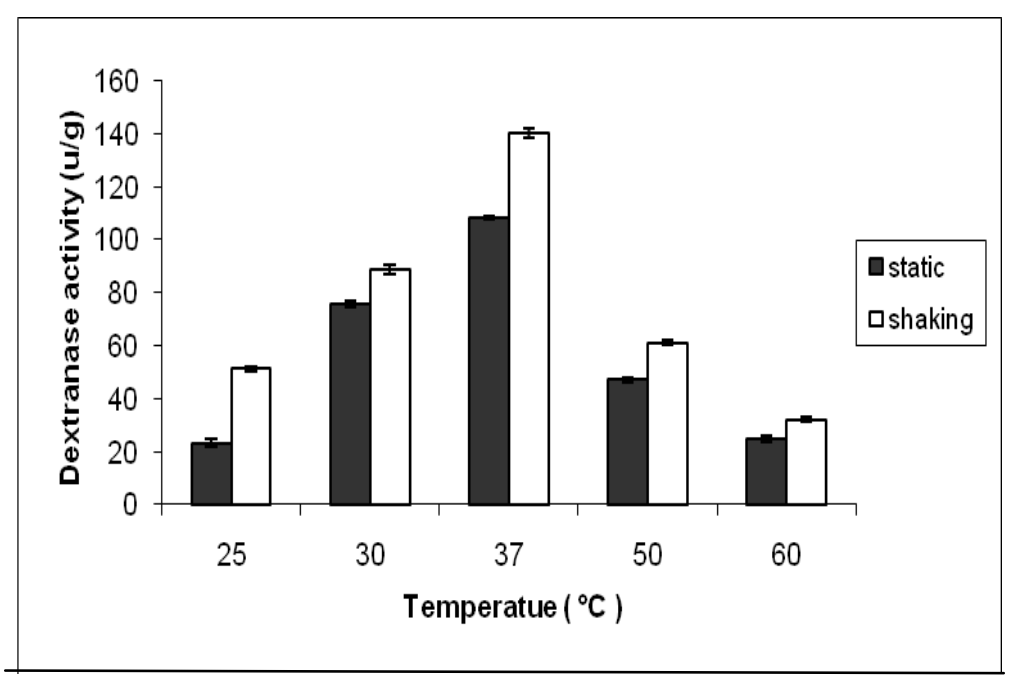

Fig. 3. Effect of different temperature on dextranse production from Bacillus subtilis KNR. 


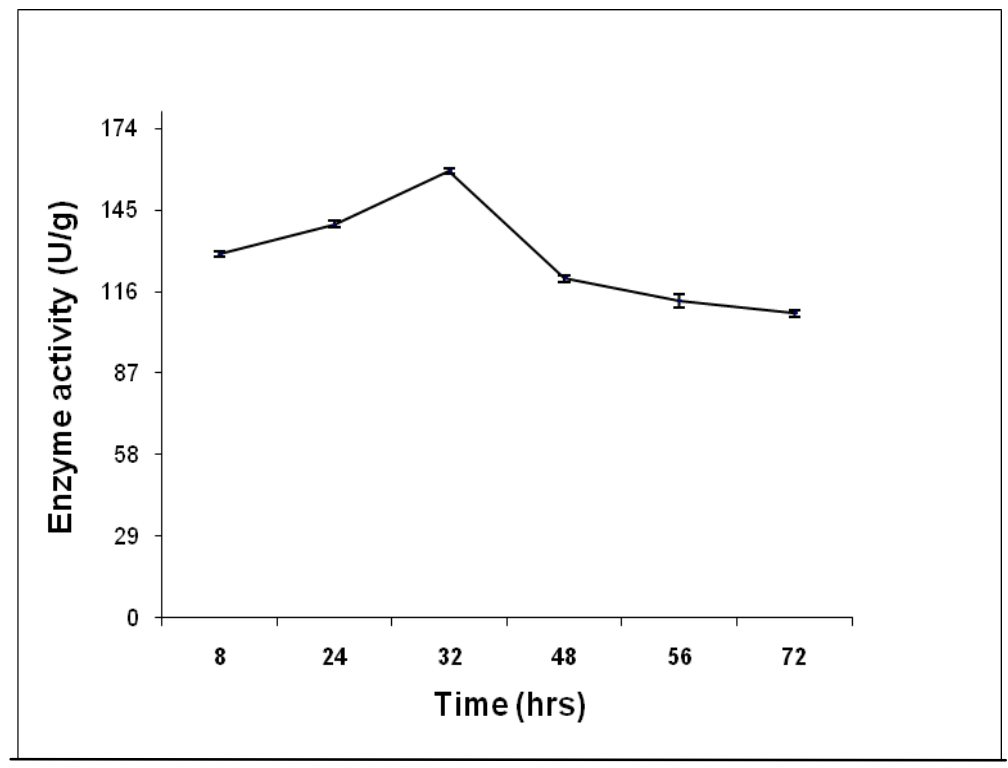

Fig. 4. Effect of incubation time on dextranase production from Bacillus subtilis KNRC.

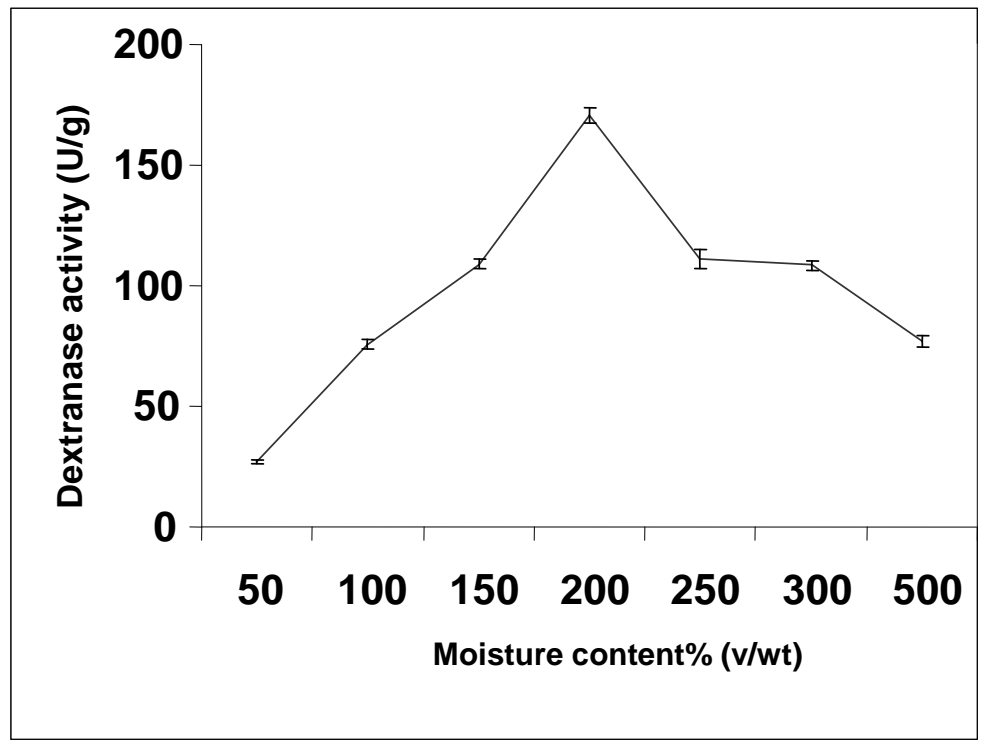

Fig. 5. Effect of different moisture content on dextranse production from Bacillus subtilis KNRC.

Egypt. J. Microbiol. 46 (2011) 


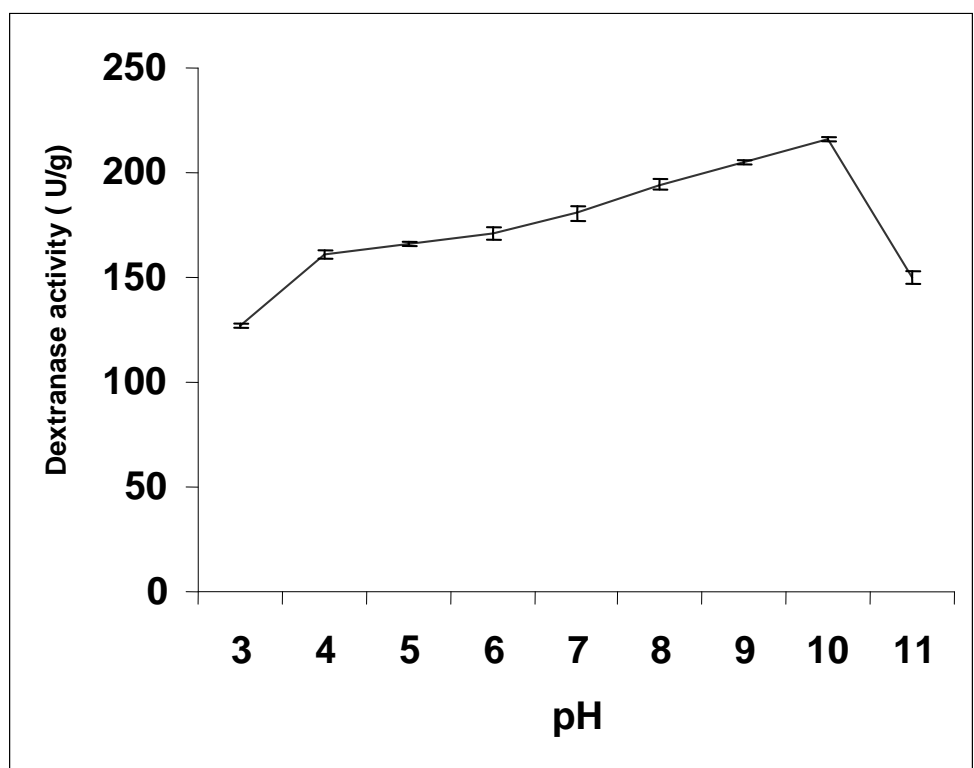

Fig. 6. Effect of different pH on dextranse production from Bacillus subtilis KNRC.

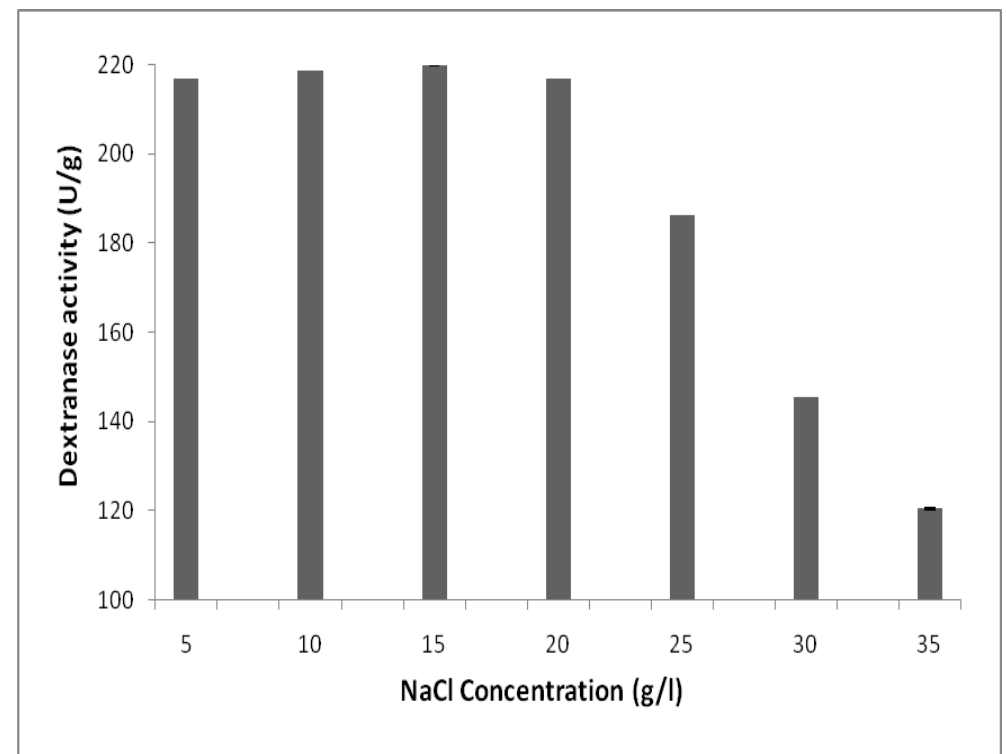

Fig. 7. Effect of different $\mathrm{NaCl}$ concentations on dextranase activity from Bacillus subtilis KNRC.

Egypt. J. Microbiol. 46 (2011) 


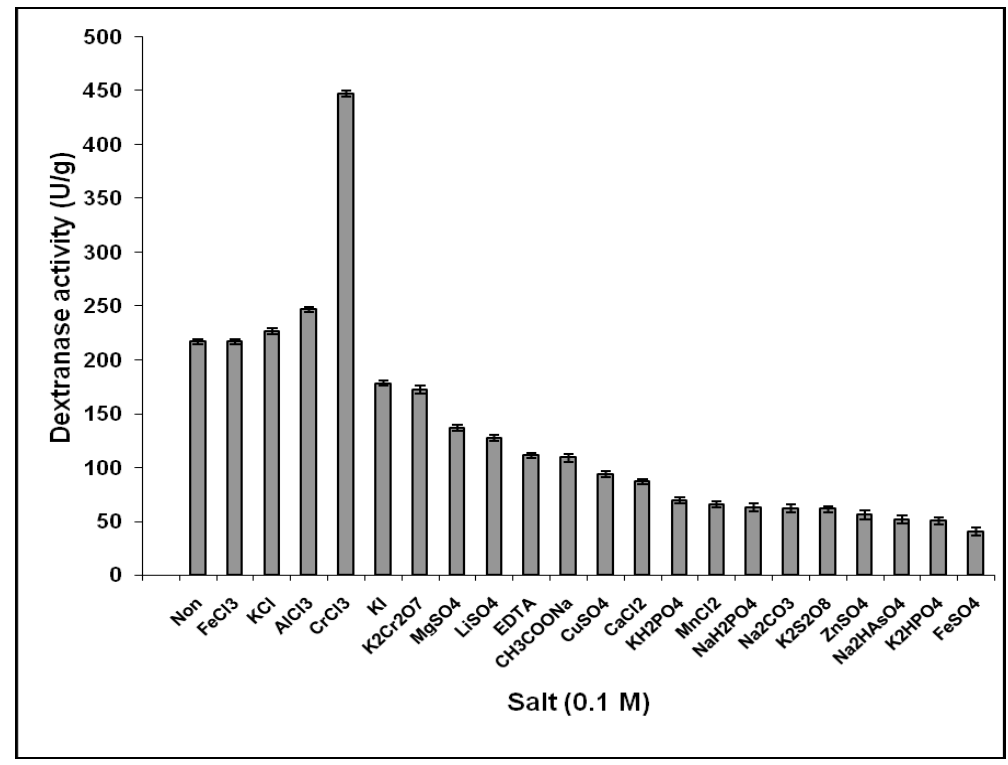

Fig. 8a. Effect of different salts on dextranase production from Bacillus subtilis KNRC.

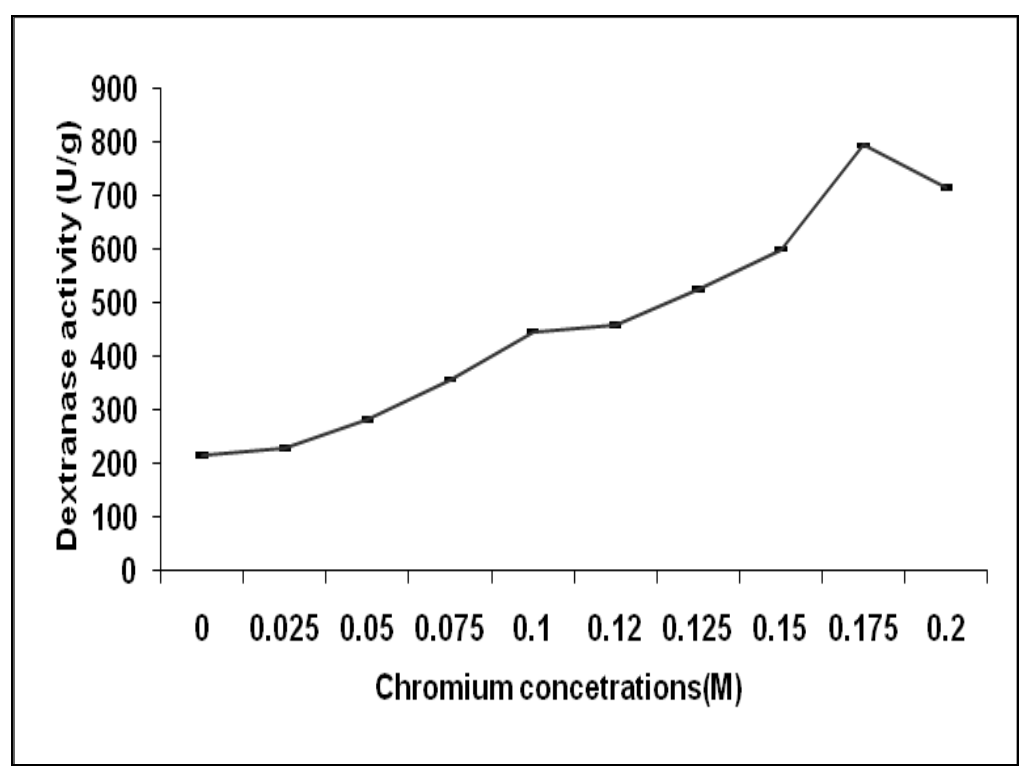

Fig. 8b. Effect of different concentrations of Chromium chloride on dextranase production from Bacillus subtilis NRC-B233.

Egypt. J. Microbiol. 46 (2011) 


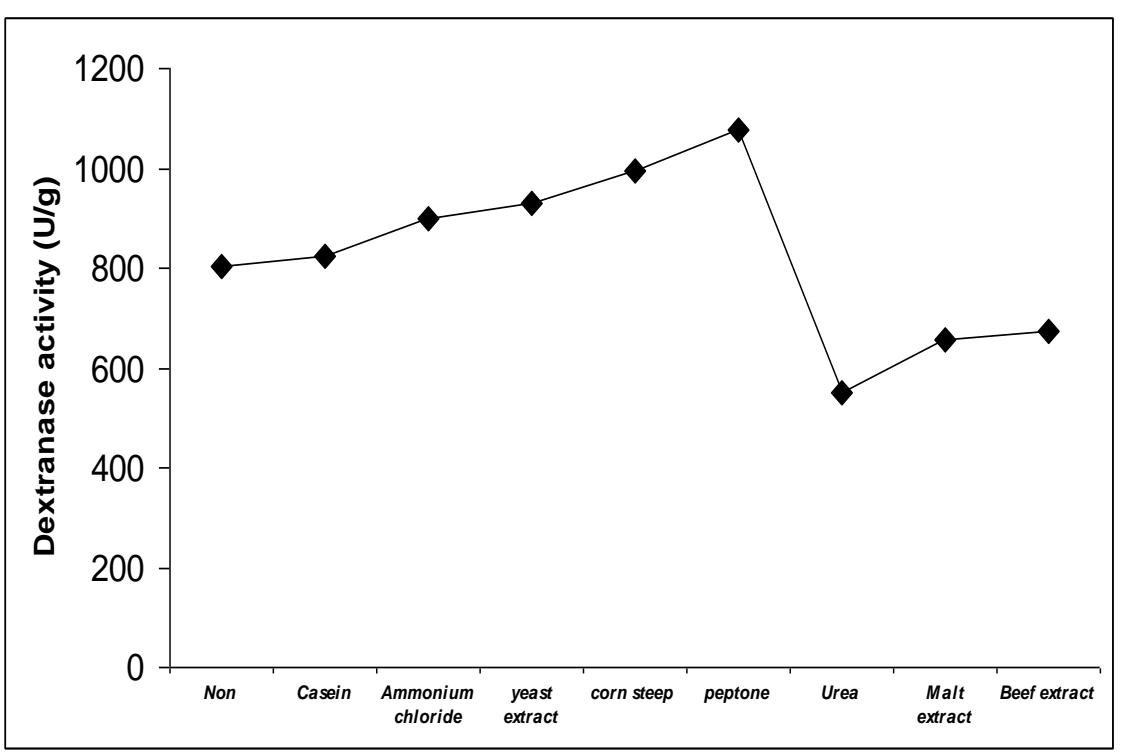

Fig. 9a. Effect of different nitrogen sources on dextranse production from Bacillus subtilis KNRC.

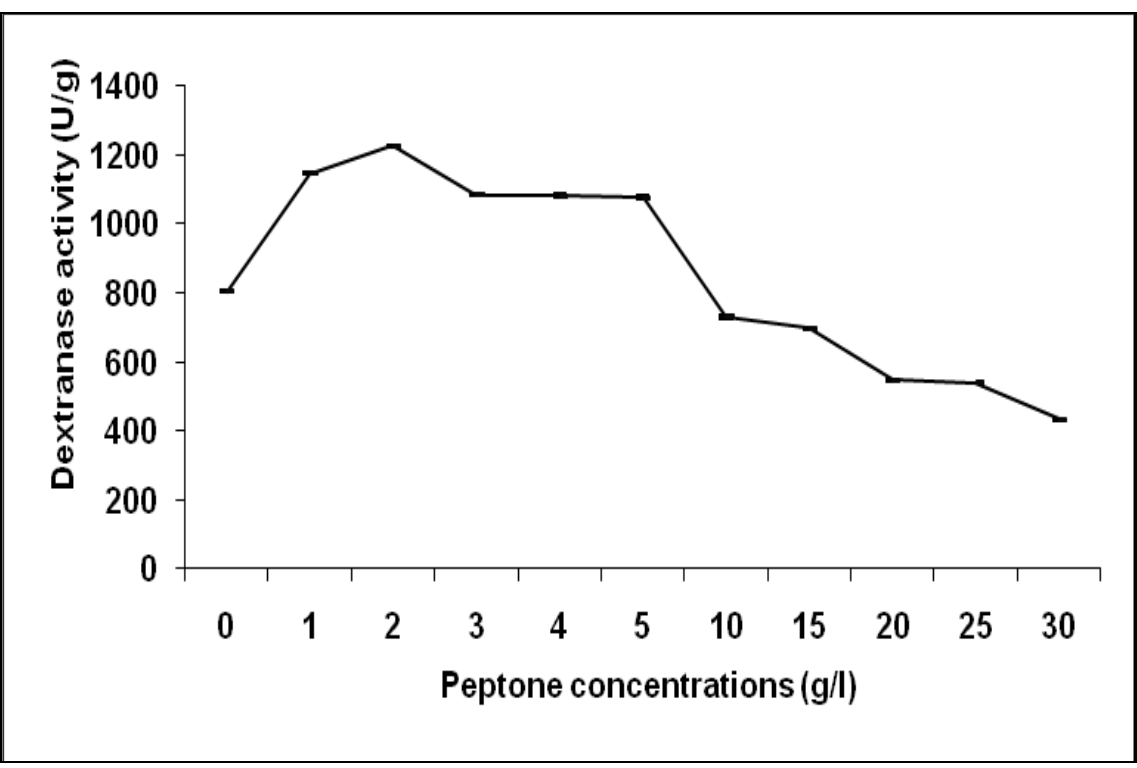

Fig. 9b. Effect of different peptone concentrations on dextranse production from Bacillus subtilis KNRC. 


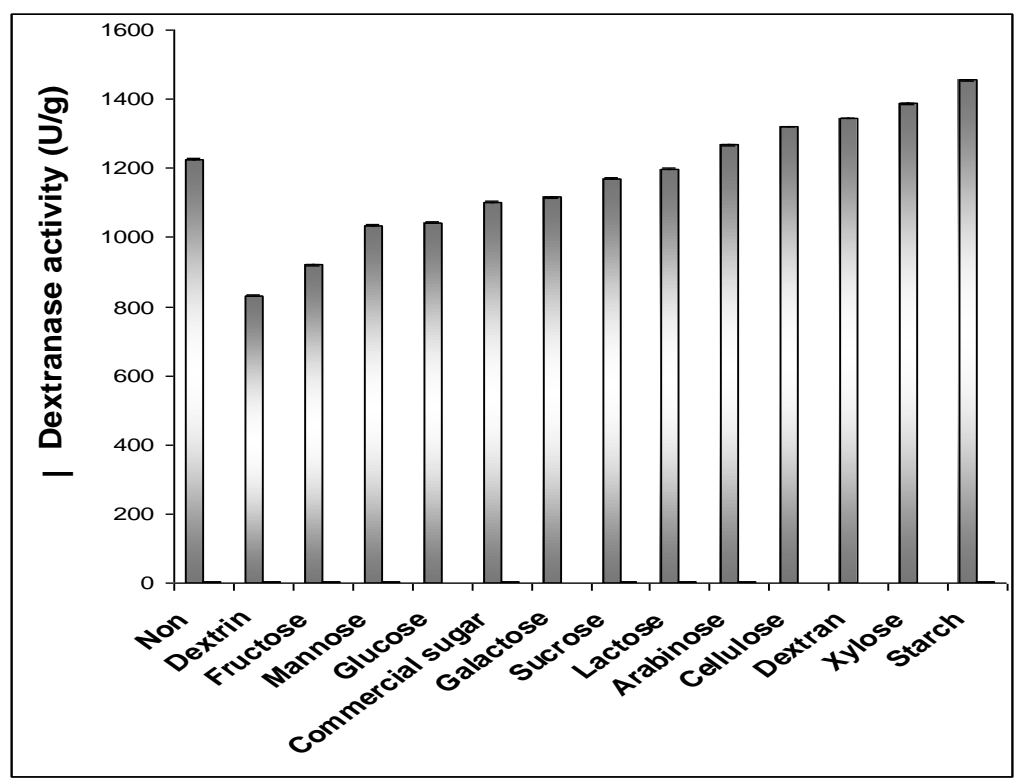

Fig. 10. Effect of different carbon sources on dextranse production from Bacillus subtilis KNRC.

Partial purification of dextranase

Ultrafilteration of the culture broth using membrane PLGC Cassette10.000 NMWL.resulted in $84.2 \%$ dextranase recovery. The result indicated that dextranase aggregated on low molecular weight cutoff membranes. The concomitant recovery of dextranase using $70 \%$ acetone showed a recovery of about $37.3 \%$ (Table 1 ).

TABLE 1. Partial purification steps of Bacillus subtilis KNRC dextranase.

\begin{tabular}{|l|c|c|c|c|c|c|}
\hline $\begin{array}{l}\text { Purification } \\
\text { steps }\end{array}$ & $\begin{array}{c}\text { Total } \\
\text { activity } \\
(\mathbf{U})\end{array}$ & $\begin{array}{c}\text { Recovered } \\
\text { activity } \\
(\boldsymbol{\%})\end{array}$ & $\begin{array}{c}\text { Total } \\
\text { protein } \\
(\mathbf{m g})\end{array}$ & $\begin{array}{c}\text { Recovered } \\
\text { protein } \\
(\boldsymbol{\%})\end{array}$ & $\begin{array}{c}\text { Specific } \\
\text { activity } \\
(\mathbf{U} / \mathbf{m g})\end{array}$ & $\begin{array}{c}\text { Fold of } \\
\text { purifica- } \\
\text { tion }\end{array}$ \\
\hline Culture filtrate & 249931 & 100.0 & 4477.4 & 100.0 & 55.8 & 1 \\
\hline Ultra filtration & 201446 & 84.2 & 1276.5 & 28.5 & 164.9 & 2.96 \\
\hline Acetone (70 \%) & 78424 & 37.3 & 12.525 & 0.0028 & 6261 & 112.2 \\
\hline
\end{tabular}

Effect of different parameters on dextranase activity

The results in Fig. 11 and 12 showed that alkaline media and high temperatures were the most favorable for the enzyme activity. Maximum activity was obtained at $\mathrm{pH} 9.2$ and $70^{\circ} \mathrm{C}$. A sharp decrease in dextranase was noticed at acidic pH (3.2 and 4.2) and at $35^{\circ} \mathrm{C}$. The thermal stability of the partially purified dextranase showed

Egypt. J. Microbiol. 46 (2011) 
that the enzyme was fairly stable to heat treatment in absence of the substrate (Table 2). At $75^{\circ} \mathrm{C}$ the enzyme retained its complete stability for one hour. The $\mathrm{pH}$ of the enzyme exhibited stability $\mathrm{pH}$ across wide range of $\mathrm{pH}$. The enzyme exhibited maximum stability at $\mathrm{pH} 10.2$ after half hour (Table 3). The effect of different salts (Fig. 13) showed that $\mathrm{NaCl}$ from (1-15\%) played a significant role in enzyme activity where the activity at $10 \%$ increased about four-fold. On the other hand, EDTA, $\mathrm{CaCl}_{2}, \mathrm{KCl}$ and $\mathrm{Mg}_{2} \mathrm{SO}_{4}$ all enhanced enzyme activation (Table 4). Whereas dextranase activity was strongly inhibited by $\mathrm{MnCl}_{2}$ and $\mathrm{AlCl}_{3}$ and the retained activities were $31.3 \%, 36.9 \%$, respectively. The substrate specificity of Bacillus subtilis KNRC on different types of carbohydrates and the rate of enzyme hydrolysis with various glycosidic linkages was done. Blue dextran (1000M.wt) gave the maximum relative enzyme activity $(273.8 \%)$ (Table 5). Substantial dextranolytic activity was found when starch ( $\alpha-1,4$ and $\alpha-1,6$ glycosidic linkages), amylopectin, maltose, inulin and cellulose ( $\alpha-1,4$ glycosidic linkages) were used as carbon sources. The crude enzyme was highly tolerant to repeated freezing and thawing, the activity remaining at $100 \%$ for three months.

TABLE 2. Thermal stability of Bacillus subtilis KNRC dextranase.

\begin{tabular}{|l|c|c|c|c|}
\hline \multirow{2}{*}{$\begin{array}{l}\text { Temperature } \\
\left({ }^{\circ} \mathbf{C}\right)\end{array}$} & \multicolumn{4}{|c|}{ Exposure time (min) } \\
\hline 40 & $100 \pm 0.031$ & $100 \pm 0.029$ & $100 \pm 0.066$ & $100 \pm 0.092$ \\
\hline 45 & $100 \pm 0.016$ & $100 \pm 0.017$ & $100 \pm 0.029$ & $100 \pm 0.008$ \\
\hline$* \quad 50$ & $100 \pm 0.003$ & $100 \pm 0.034$ & $100 \pm 0.033$ & $100 \pm 0.049$ \\
\hline 55 & $100 \pm 0.022$ & $100 \pm 0.021$ & $100 \pm 0.050$ & $100 \pm 0.053$ \\
\hline 60 & $100 \pm 0.020$ & $100 \pm 0.019$ & $100 \pm 0.070$ & $100 \pm 0.030$ \\
\hline 65 & $100 \pm 0.046$ & $100 \pm 0.080$ & $100 \pm 0.090$ & $100 \pm 0.027$ \\
\hline 70 & $100 \pm 0.060$ & $100 \pm 0.005$ & $100 \pm 0.037$ & $100 \pm 0.025$ \\
\hline 75 & $100 \pm 0.009$ & $100 \pm 0.034$ & $80.6 \pm 0.030$ & $80.6 \pm 0.057$ \\
\hline
\end{tabular}

Relative values of dextranase activity of enzyme, expressed in \% and obtained by Berridge's method * Control (The original temperature)

TABLE 3. pH stability of the partially purified Bacillus subtilis KNRC dextranase .

\begin{tabular}{|l|c|c|c|c|}
\hline \multirow{2}{*}{$\mathbf{p H}$} & \multicolumn{4}{|c|}{ Exposure time (min) } \\
\cline { 2 - 5 } & $\mathbf{3 0}$ & $\mathbf{6 0}$ & $\mathbf{9 0}$ & $\mathbf{1 2 0}$ \\
\hline $5.20^{*}$ & $100 \pm 0.031$ & $100 \pm 0.029$ & $90 \pm 0.066$ & $83 \pm 0.092$ \\
\hline 6.20 & $100 \pm 0.016$ & $100 \pm 0.017$ & $100 \pm 0.029$ & $100 \pm 0.008$ \\
\hline 7.2 & $100 \pm 0.003$ & $100 \pm 0.034$ & $100 \pm 0.033$ & $100 \pm 0.049$ \\
\hline 8.2 & $100 \pm 0.022$ & $100 \pm 0.021$ & $100 \pm 0.050$ & $100 \pm 0.053$ \\
\hline 9.2 & $100 \pm 0.020$ & $100 \pm 0.019$ & $100 \pm 0.070$ & $100 \pm 0.030$ \\
\hline 10.2 & $100 \pm 0.046$ & $95 \pm 0.080$ & $81 \pm 0.090$ & $80 \pm 0.027$ \\
\hline
\end{tabular}

Relative values of dextranase activity of enzyme, expressed in \% and obtained by Berridge's method.

* Control (The origonal temperature)

TABLE 4. Effect of different salts on Bacillus subtilis $\mathrm{K}$ dextranase activity. 


\begin{tabular}{|l|c|}
\hline $\begin{array}{l}\text { Salt } \\
(\mathbf{0 . 1} \mathbf{~ M})\end{array}$ & Relative activity (\%) \\
\hline$* \mathrm{Non}$ & $100 \pm 0.008$ \\
\hline $\mathrm{MnCl}_{2}$ & $31.3 \pm 0.001$ \\
\hline $\mathrm{CrCl}_{3}$ & $125 \pm 0.031$ \\
\hline $\mathrm{EDTA}$ & $264.4 \pm 0.053$ \\
\hline $\mathrm{CaCl}_{2}$ & $228.8 \pm 0.22$ \\
\hline $\mathrm{MgSO}_{4}$ & $181.25 \pm 0.029$ \\
\hline $\mathrm{NaCl}$ & $104.9 \pm 0.024$ \\
\hline $\mathrm{CuSO}_{4}$ & $77.5 \pm 0.064$ \\
\hline $\mathrm{AlCl}_{3}$ & $36.9 \pm 0.006$ \\
\hline $\mathrm{CaCO}_{3}$ & $100 \pm 0.027$ \\
\hline $\mathrm{KCl}$ & $207.6 \pm 0.015$ \\
\hline $\mathrm{ZnSO}_{4}$ & $84.5 \pm 0.019$ \\
\hline
\end{tabular}

* Control (without any salt)

TABLE 5. Action of Bacillus subtilis NRCK dextranase on various carbohydrates.

\begin{tabular}{|l|c|c|}
\hline \multicolumn{1}{|c|}{ Dextran type } & Main linkage & Relative activity (\%) \\
\hline $\begin{array}{l}\text { Dextran * } \\
(250.000 \mathrm{M} . w \mathrm{t})\end{array}$ & $\alpha-1,6$ & 100 \\
\hline $\begin{array}{l}\text { Dextran } \\
(200.000-275.000 \text { M.wt) }\end{array}$ & $\alpha-1,6$ & 79.2 \\
\hline $\begin{array}{l}\text { Blue dextran } \\
(2000 \text { M.wt) }\end{array}$ & $\alpha-1,6$ & 273.8 \\
\hline $\begin{array}{l}\text { Sephadex G-100 } \\
(1000-10.000 \mathrm{Mt})\end{array}$ & $\alpha-1,6$ & 112 \\
\hline Starch & $\alpha-1,6$ & 228 \\
\hline Amylopectin & $\alpha-1,6$ & 165 \\
\hline Maltose & $\alpha-1,4$ & 71 \\
\hline Cellulose & $\alpha-1,4$ & 100 \\
\hline Inulin & $\alpha-1,4$ & 170 \\
\hline
\end{tabular}

*Control

Egypt. J. Microbiol. 46 (2011) 


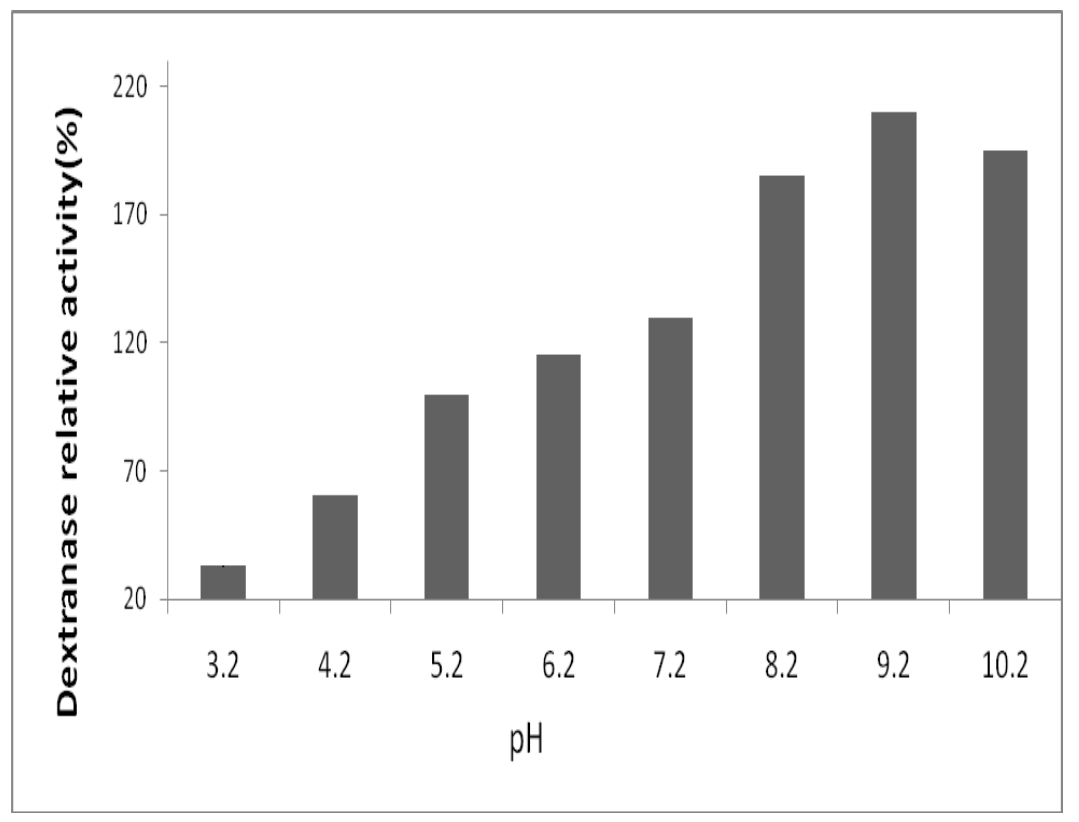

Fig. 11. Effect of different $\mathrm{pH}$ on partial purified dextranse.

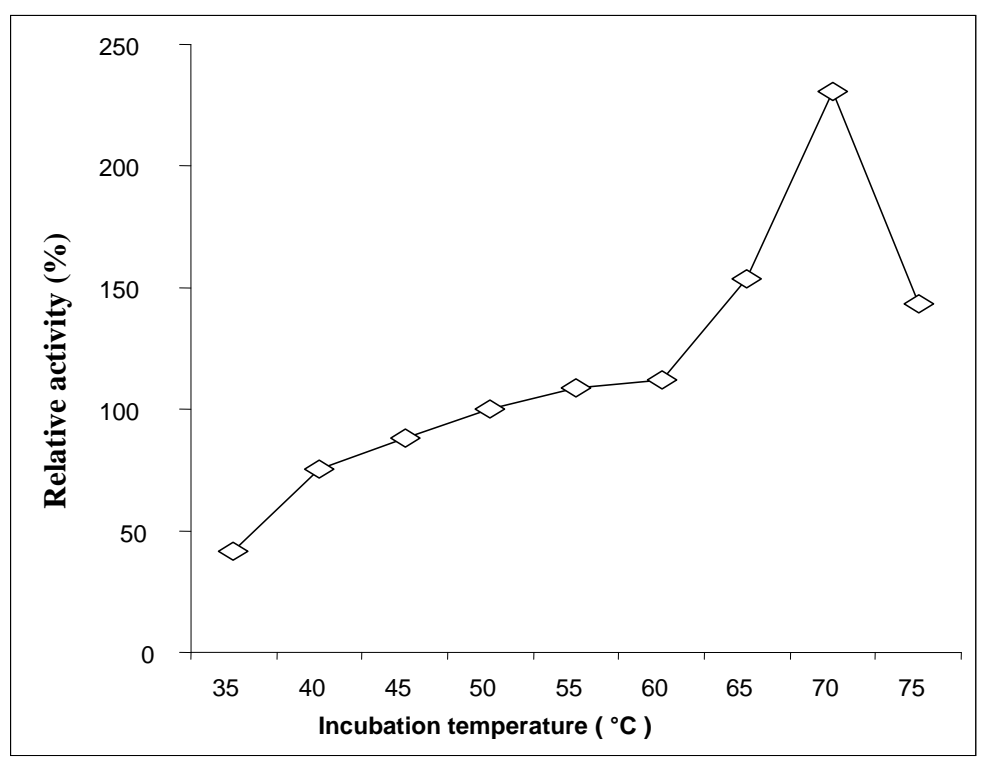

Fig. 12. Effect of different temperatures on partial purified dextranse.

Egypt. J. Microbiol. 46 (2011) 


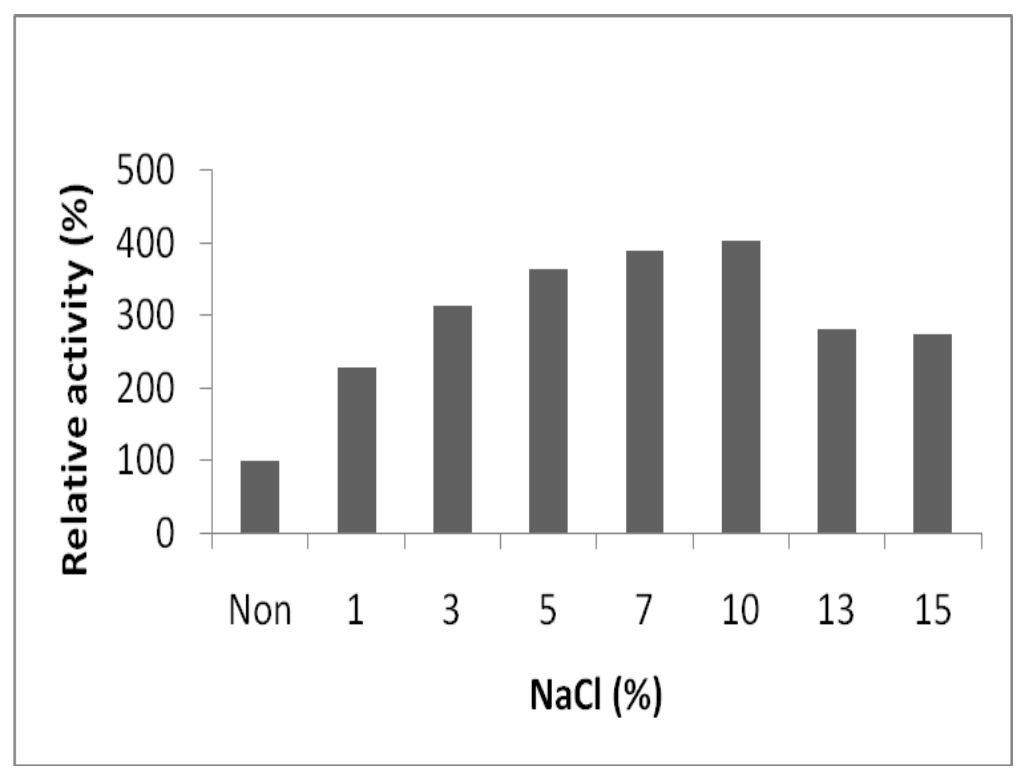

Fig. 13. Effect of different $\mathrm{NaCl}$ concentrations on partial purified dextranse.

\section{Discussion}

The Bacillus subtilis isolate (NRC-B233) obtained from Saudia Arabian honey was shown to have substantial potential as a dextranase producer in a range of substrates, temperatures and $\mathrm{pH}$ levels. It was selected for further studies since it appeared to be the best producer of extracellular dextranase. The chromatography products from dextran MT 250000 with crude enzyme suggested a random endo-type hydrolysis resulting in the liberation of long-chain oligomers together with glucose and isomaltose units. Unique characters of this isolate was its ability to produce dextranase in the absence and presence of $\mathrm{NaCl}$ (5-25 g/l) without a reduction in enzyme production. In contrast, Abdel - Naby et al. (1999) reported that using of starch instead of dextran led to a drastic decrease in enzyme production. They showed that the major regulatory mechanism of dextranase is constitutive. The mutant Lipomyces starkeyi produced constitutive dextranase when grown on glucose, fructose and sucrose as well as on dextran (Kim \& Day, 1995). In the present study, enzyme productivity was significantly affected by temperature and $\mathrm{pH}$, with the optimum enzyme production was at $37^{\circ} \mathrm{C}$ and $\mathrm{pH}$ 9. Similar results were reported by Yamsguchi \& Gocho (1973) since Brevibacterium dextranase had an optimum dextranase activity at $\mathrm{pH} 8.0$ and $37^{\circ} \mathrm{C}$. In contrast, Bhatia et al. (2010) showed that maximum dextranase production by Paecilomyces lilacinus was achieved at $\mathrm{pH} 6.0$ and at temperature $30^{\circ} \mathrm{C}$. In the present study, the most potent activity of the enzyme was noticed at $200 \%$ (v/wt) moisture level. Whilst nitrogen sources including organic and inorganic nitrogen showed that corn steep and peptone were the most effective for enzyme production. Yamsguchi \& Gocho (1973),

Egypt. J. Microbiol. 46 (2011) 
reported that polypeptone was the most effective nitrogen source for Brevibacterium dextranase production among the compounds tested. $\mathrm{CrCl}_{3}$ increased enzyme productivity by more than two-fold. $\mathrm{CrCl}_{3}$ could play an important role as a dextranase stimulator.

The use of ultrafilteration for downstream processing would result in a onestep, cost-effective method of recovery for dextranase. The molecular weight of the partially purified enzyme was less than $10 \mathrm{KDa}$. The halophilic bacteria's enzymes are thus active at salt concentrations which inhibit or even denature many enzymes of non-halophilic organisms. This must be reflected in marked differences in the composition and properties of the protein molecules (Norberg \& Hofsten, 1969). It was suggested that the halophilic enzymes have smaller molecular weight than most other enzymes, which would make them more resistant to being 'salted' out. However, no halophilic dextranase have yet been studied in sufficient detail to give substantial support to this hypothesis.

The properties of the partially purified enzyme clearly showed that high temperature and alkaline media were the most favorable for the enzyme activity. The enzyme showed optimal activity at $70^{\circ} \mathrm{C}$, indicating that an increase in activity with temperature offsets the thermal denaturation. It was reported that the optimal temperature for Thermotoga lettingae TMO dextranse was $55-60^{\circ} \mathrm{C}$ during 15 min incubation (Kim \& Kim, 2010). The optimum $\mathrm{pH}$ for dextranase activity was 9 . In contrast Wynter et al. (1996) reported that ammonium sulfate precipitated crude dextranase with its optimum $\mathrm{pH}$ between 5 and 6 . The use of ultrafilteration for downstream processing would result in a one-step, costeffective method of recovery. The partially purified dextranase was greatly affected by the addition of metal ions, the halophilic feature of this enzyme appeared clearly, when the enzyme activity increased about four-fold in the presence of $10 \% \mathrm{NaCl}$. Thus, the effects of salt concentration on the efficiency of dextranase productin should be an interesting study to conduct in the future. Sugiura et al., (1973) reported that dextranase from Penicillium funiculosum was activated by $\mathrm{Co}^{2+}, \mathrm{Mn}^{2+}$ and $\mathrm{Cu}^{2+}$ and inactivated by $\mathrm{Ag}^{+}, \mathrm{Hg}^{2+}, \mathrm{N}-$ bromosuccinimide and iodine. In contrast, Thermotoga lettingae TMO dextranase activity was not significantly affected by the presence of metal ions, except for the strong inhibition by $1 \mathrm{mM} \mathrm{Fe}{ }^{2+}$ and $\mathrm{Ag}^{2+}$ (Kim \& Kim, 2010). The enzyme showed complete stability at $75{ }^{\circ} \mathrm{C}$ till one hour. In contrast, the alkaline dextranase from Brevibacterium was stable at temperatures below $60^{\circ} \mathrm{C}$ (Yamsguchi \& Gocho, 1973). An attractive industrial application of thermostable dextranase is sugar processing. Penicillium sp. and Chaetomium gracile dextranases that are active and stable above $55^{\circ} \mathrm{C}$ would improve processing of dextran-contaminated cane juice in the sugar industry (Khalikova et al., 2005). In the present study, the partially purified dextranse exhibited a broad $\mathrm{pH}$ stability range ( $\mathrm{pH} 4.3-10.0)$, especially on the alkaline side. Similar results were reported by Kim \& Kim (2010). The broad pH stability of our enzyme could be useful in sugar processing, which involves both acidic and alkaline conditions. This enzyme could act efficiently on high and low molecular weight dextranase. Where it could preferentially split a series of dextrans and their derivatives 
(Sephadex), but in the case of dextrans, the rate of hydrolysis was dependent on the molecular weight of the substrate. Pleszczyńska et al. (1996) reported that Penicillium notatum dextranase which could act on different types of dextran and the rate of hydrolysis was independent of the molecular weight of substrate. The digestion products from the Sephadex derivatives showed the presence of reducing sugars. The previous result suggests dextranase to be an enzyme available for removal of dental cariogenic plaque deposits (Lifschitz \& Bauer, 1976).

A great dextranolytic activity was found when starch, $(\alpha 1,4$ and $\alpha-1,6$ glycosidic linkages) and amylopectin $(\alpha 1,4)$. Competition studies with different amounts of dextran and starch as substrates showed consistency with the hypothesis that hydrolysis of dextran and starch occurs at two independent active sites (Kim et al., 2001., Lee et al., 2003 and Ryu et al., 2000). Degradation of alpha-linked D-gluco-oligosaccharides and dextrans by an isomalto-dextranase preparation from Arthrobacter globiformis T6 was reported by Torii et al., (1976).

\section{Conclusion}

In this study we focused on the isolation of halophilic bacteria from honey as a new source of bacteria producing dextranase. The honey isolate produced a novel halophilic low molecular weight constitutive dextranase characterized by unique features, like thermostability and $\mathrm{pH}$ stability. Further, cheap substrates like corn starch would be a superior alternative to the already available expensive dextran, since $30-40 \%$ of the production cost of industrial enzymes is accounted by the cost of the growth medium.

\section{References}

Abdel-Naby,M.A., Ismail, A.M.S., Abdel-Fattah, A.M. and Abdel-Fattah, A.F. (1999) Preparation and some properties of immobilized Penicillium funiculosum 258 dextranase. Process Biochem, 34, 391-398.

Amoozegar, M.A., Malekzadeh, F. and Malik, K.A. (2003) Production of amylase by newly isolated moderate halophile, Halobacillus sp. Strain MA-2. J. Microbiol. Methods, 52, 353-359.

Ash, C., Farrow, J.A.E., Wallbanks, S. and Collins, M.D. (1991) Phylogenetic heterogeneity of the genus Bacillus as revealed by comparative analysis of small subunit-ribosomal RNA sequences. Lett. App. Microbiol. 13:202-206.

Ausubel, F.M., Brent, R., Kingston, R.E., More, D.D., Seidam, J.G. Smith, J.A. and Struhl, K. (Ed). (1999) "Short protocols in Molecular Biology". John Willey and Sons, Inc. NY.

Bhatia, S., Bhakri, G., Arora, M., Uppal, S. K. and Batta, S. K. (2010) Dextranase production from Paecilomyces lilacinus and its application for dextran removal from sugarcane juice $\mathrm{V}, 133-138$.

Egypt. J. Microbiol. 46 (2011) 
Balch, W.E., Fox, G.E., Magrum, R.J. and Wolfe, R.S., (1979) Methanogens: reevaluation of a unique biological group. Microbiol. Rev., 43, 260-296.

Block, R.J., Durrum, E.L. and Zweig, G. (1995) A manual of paper chromatography and paper electrophoresis.New York, NY: Academic, pp. 127.

Clarke, M. (1997) Dextranase in Sugar Factories: Causes And Control, part I. Sugary Azucar 92, pp. 38-46.

Freeman, M., Baehler, C. and Spotts, S. (1990) Automated Lazer fluorescence sequencing. Biotechnol. 8, 147-148.

Fukomoto, J. (1963) The culture conditions of Rhizopus delemar and its lipase production. Kagaku to Kogyo ( Osaka ), 40, 80 - 89.

Hall, T.A. (1999) BioEdit: a user- friendly biological sequence alignment editor and analysis program for Windows 95/98/NT.Nucl. Acid. Symp. Ser. 41, 95-98.

Hayward, A.C. and Sly, L. I. (1976) Dextranase acyivity in Oerskovia Xanthineolytica. J. Appl. Bact. 40, 355 - 364.

Hutcheon, G.W., Nishi, V. and Albert, B. (2005) Characterization of a highly stable amylase from the halophilic archaeon Haloarcua hispanica, Extremophiles 9 , 487492.

Khalikova, E., Susi, P. and Korpela, T. (2005) Microbial Dextran-Hydrolyzing Enzymes: Fundamentals and Applications Microbiol. Mol. Biol. Reviews, 69, 306325 .

Kim, D. and Day, D. F. (1995) Isolation of a dextranase constitutive mutant of Lipomyces starkeyi and its use for the production of clinical size dextran. Letters in Applied Microbiology, 20, 268-270.

Kim, D.W., Heo, S. J. and Ryu, S.J. (2001) Enzyme capable of hydrolyzing plaque, microorganism producing the same, and a composition comprising the same. WO Patent Publication 01/66570.

Kim,Y.M. and Kim, D. (2010) Characterization of novel thermostable dextranase from Thermotoga lettingae TMO. Appl. Microbiol. Biotechnol. 85, 581-58.

Lee, S.Y., Lee, J.H., Robyt, J. F., Seo, E.S., Park, H.J., and Kim, D. (2003) Demonstration of two independent dextranase and amylase active sites on a single enzyme elaborated by Lipomyces starkeyi KSM 22. J. Microbiol. Biotechnol 13, 313 316.

López, A.C. and Alippi, A.M. (2007) Phenotypic and genotypic diversity of Bacillus cereus isolates recovered from honey, Int. J. Food Microbiol . 117, 175-184.

Lowery, O.H., Rosenbrough , N.J., Farr, A.L. and Ranadall, R.J. (1956) Protein measurement with the folin phenol reagent. J. Biol. Chem. 193, $265-276$. 
Lifschitz, B.G. and Bauer, S. (1976) Comparison of dextranases for their possible use in eliminating dental plaque. J. Dent. Res. 55, $886-892$.

Margesin, R. and Schinner, F. (2001) Bioremediation (natural attenuation and biostimulation) of diesel-oil-contaminated soil in an alpine glacier skiing area Appl. Environ. Microbiol, V, 3127-3133.

Norberg, P. and Hofsten, B.V. (1969) Proteolytic enzymes from extremely halophilic bacteria J. Gen. Microbiol, 55, 251-256.

Oren, A., Frank, L., Richardson, P.A.L. and Laszlo, N.C. (2005) How to be moderately halophilic with broad salt tolerance; clues from the genome of Chromohalobacter salexigens, Extremophiles, 9, 275-279.

Page, R.D.M. (1996) TREEVIEW: An application to display phylogenetic trees on personal computers. Computer Applications in the Biosciences, 12,357-358.

Pandey, A. (1994) in "Solid State Fermentation" (Pandey, A(Ed.), Wiley Eastern Publishers, New Delhi, pp. 3-10.

Pandey, A. (1992) Recent process developments in solid-state fermentation, Process Biochem. 27, 109-117.

Pleszczyńsk, M., Rogalsk, J. I., Szczodrak., J. and Fiedurek, J. (1996) Purification and some properties of an extracellular dextranase from Penicillium notatum Mycol. Res, 100, 681-686.

Prober, J.M., Trainor, G.L., Dam, R.J., Hobbs, F.W., Robertson, C.W., Zagursky, R.J., Cocuzza, A.J., Jensen, M.A. and Baumeister, K. (1987) A system for rapid DNA sequencing with fluorescent chain-terminating dideoxynucleotides. Science, 238, 336-341.

Puri, S., Beg, Q.K. and Gupta, R. (2002) Optimization of alkaline protease production from Bacillus sp. using response surface methodology. Curr. Microbiol. 44, 286-90.

Rodriguez, H., de las Rivas, B. and Muňoz, R. (2007) Efficacy of recA gene sequence analysis in the identification and discrimination of Lactobacillus hilgardii strains isolated from stuck wine fermentations. Inter. J. Food. Microbio. 115, 70-78.

Ryu, S.J., Kim, D., Ryu, H.J., Chiba, S., Kimura, A. and Day, D.F. (2000) Purification and partial characterization of a novel glucanhydrolase from Lipomyces starkeyi KSM 22 and its use for inhibition of insoluble glucan formation. Biosci. Biotechnol. Biochem. 64, 223-228.

Sanger, F., Nicklen,S. and Coulson, A.R. (1977) DNA sequencing with chain terminating inhibitors. Proc. Natl. Acad. Sci. 74, 5463-5467.

Sambrook, J., Fritsch, E.F. and Maniatis, T. (1989) "Molecular Cloning A. Laboratory Manual". Cold Spring Harbor Laboratory, NY. 
Sankpal, N.V., Joshi, A.P., Sainkar, S. R. and Kulkarni, B. D. (2001) Production of dextran by Rhizopus sp. Immobilized on porous cellulose support. Process Biochem.37, 395-403.

Shah, M.M., Lihara, H., Noda, M., Song, S.X., Nhung, P.H., Ghkusu, K. K., Awamura, Y. and Ezaki, T. (2007) dnaJ gene sequence-based assay for species identification and phylogenetic grouping in the genus Staphylococcus. Int. J. Syst. Evol. Microbiol. 57, 25-30.

Somogy, M. (1952) Notes on sugar determination. The Journal of Biological of Chemistry, 195, 19-23

Sugiura, A., Akira, A., Ogiso, T., Kato, K. and Asano, H. (1973) Studies on dextranase: Purification of dextranase from Penicillium funiculosum and its enzymatic properties. Biochim. Biophys. Acta, BBA-Enzymology 309, 357-362.

Tokunaga, H., Ishibashi, M., Arakawa, T. and Tokunaga, M. (2004) Highly efficient renaturation of $\beta$-lactamase isolated from moderately halophilic bacteria, FEBS letteres 558, 7-12.

Torii, M., Sakakibara, K., Misaki, A. and Sawai, T. (1976) Degradation of alphalinked D-gluco-oligosaccharides and dextrans by an isomalto-dextranase preparation from Arthrobacter globiformis T6. Biochem. Biophys. Res. Commun. 70, 459-464.

Ventosa, A., Nieto, J.J. and Oren, A. (1998) Biology of moderately halophilic aerobic bacteria. Microbiol. Mol. Biol. Rev. 62, 504-544

Wynter, C., Patel, B. K. C. B. K. C. Peter Bain, J. de Jersey, S. Hamilton, P.A. and Inkerman, A. (1996) Novel thermostable dextranase from a Thermoanaerobacter species cultured from the geothermal waters of the Great Artesian Basin of Australia FEMS Microbiol Letters, 140, 271-276.

Yamsguchi, T. and Gocho, S. (1973) Production and properties of alkaline dextranase from a newly isolated brevibacterium, Agr. Biol. Chem. 37, $2527-2533$.

Xue, Y., Ventosa, A., Wang, X., Ren, P., Zhou, P. and Ma, Y. (2008) Bacillus aidingensis sp. nov., a moderately halophilic bacterium isolated from Ai-Ding salt lake in China. Int. J. Syst. Evol. Microbiol. 58, 2828-283.

(Received $9 / 2 / 2011$; accepted 26/5/2011) 


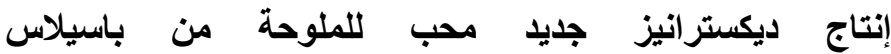 ساتلس KNRC المتحور و المعزول من العسل تحت ظروف باست

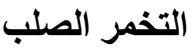

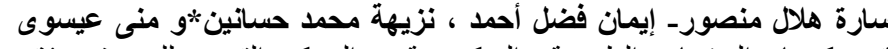

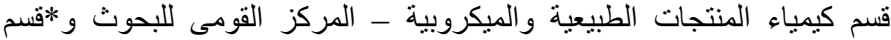 \\ الميكروبيولوجى- كلية العلوم- جامعة عين شمس- الطقاهرة- مصر.

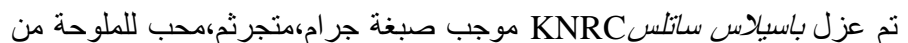 \\ عسل النحل المستورد من الملكة العربية السعودية. عرفت العيلة البكتبريا باستخدام \\ 16sRNA

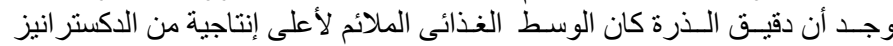 \\ (61.323 U/g)

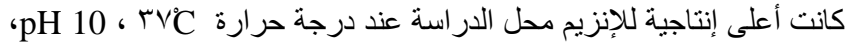 \\ وفترة تحضين 23h و 200\% نسبة ماء حيث وصلت إنتاجية الإنزيم ( 170.624 و \\ عند استخدام العديد من مصادر الكربون والنيتروجين فى الوسط الغذائى (لئي

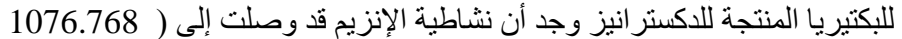

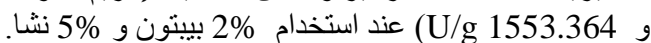 \\ إن الصفة النادرة لهذه البكتيريا هى قدرتها على إنتاج الإنزيم باستخدام وسط

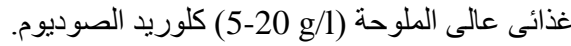 \\ إن إضافة 0.175 من كلوريد الكروميوم قد أدى إلى مضاعفة النشاطية \\ الإنزيمية أربع مرات ونصف. \\ عند استخدام الأشعة فوق البنفسجية لعمل تحور في البكتيريا المنتجة

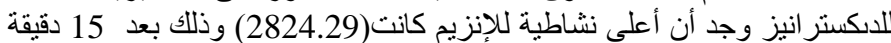 \\ من تعرض البكتيريا للأشعة.

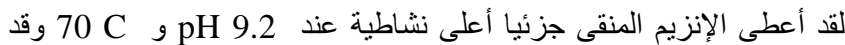 \\ زادت إنتاجية الإنزيم أربعة أضعاف بإضافة 10\% كلوريد الصوديوم.

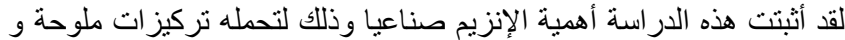

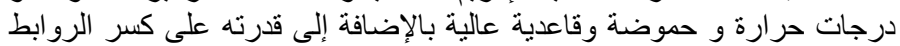 \\ من نوع
}

